\title{
ETHIOPIANISM IN PAN-AFRICAN PERSPECTIVE, 1880-1920
}

\author{
Graham A. Duncan \\ University of Pretoria \\ graham.duncan@up.ac.za
}

\section{ABSTRACT}

This article surveys the origins, development and extent of Ethiopianism (part of the African Initiated Church Movement [AIC]) in Africa which was widespread throughout Africa during the 'high' imperial and missionary era (1880-1920) which is the main focus of this article. However, they appear to have a number of common features - response to colonialism, imperialism and the missionary movement, the response of nationalism in the political sphere and Pan-Africanism linked to Ethiopianism in the religious sphere. This article seeks to explore these sometimes indistinguishable features, through selected examples, in a novel way as a Pan-African movement.

Keywords: Ethiopianism; Pan-Africanism; African Initiated Church; EW Blyden; WEB Du Bois; Rev. PJ Mzimba

\section{INTRODUCTION}

Oh! How I long for that day, when the darkness and gloom have passed away, because the "Sun of Righteousness has risen with healing in His hand". This shall be the dawning of a brighter day for the people of Africa. Christianity will usher in a new civilisation, and the "Dark Continent" will be transformed into a land of commerce and Christian institutions. Then shall Africa take her place as a nation among the nations: then shall her sons and daughters sing aloud: "Let us arise and shine, for our light has come. The glory of the Lord has risen upon us." May the day speedily come when "Ethiopia shall stretch out her hands unto God".

1 John L. Dube, 'The Ethiopian call to Africa' Extracts from J.L. Dube, 'A talk to my native land', T. Karis and G. Carter (ed.), From protest to challenge: A documentary history of African politics in South Africa, 1882-1964, vol. I, Protest and hope, 1882-1934 (Stanford California: Hoover Institute Press), 68-69.

\section{UNISA $\cong$}

Studia Historiae Ecclesiasticae Volume 41 | Number 2 | 2015 pp. 198-218
DOI: http://dx.doi.org/10.17159/2412-4265/2015/85 Print ISSN 1017-0499 | Online 2412-4265 (C) 2015. Studia Historiae Ecclesiasticae 
'Ethiopianism became a generic term to describe a whole range of the black man's [sic] efforts to improve his religious, educational, and political status in society'. ${ }^{2}$ This expresses a problem; it cannot be defined simply as a religious phenomenon. The rise of the Ethiopian church movement, the first expression of independency ${ }^{3}$ in the African ecclesiastical context, towards the end of the nineteenth century, signified the emergence of a brand of African church often referred to as 'secessionist' ${ }^{4}$ because Africans left the missions and mission churches to initiate and safeguard authentic African Christian development through the indigenisation of the church in governance, leadership and means of expression. Ethiopianism also refers to subsequent secessions which occurred in Ethiopian-type churches. Ethiopian roots can be traced to biblical times and the then known regions of northern Africa. This Pan-African expression of Christianity was based on the text of Psalm 68:31: 'Ethiopia shall soon stretch out her hands unto God.' It encapsulated a sense of cultural and political identity amongst black people throughout the African continent as an affirmation of the place black people have in God's salvific plan. The text is related to the conversion of the Ethiopian chamberlain (Acts 8:26-40) and demonstrates how Africa responded to the call of God prior to the arrival of European Christianity. Ethiopia came to represent the entire African continent and diaspora both in the sense of political freedom and African leadership and inspiration.

Members of Ethiopian-type churches were aware of the mission imperative as they themselves were the result of its effect on Western mission agencies. They were essentially indigenous mission-oriented bodies, had been touched by the gospel message and Western missionary activity and had themselves been responsible for much mission work.

Negatively, the rise of the Ethiopian movement is the result of long-standing resentment of and resistance to white domination. Missionaries were not exempt from this perception, however benevolent they appeared. The denigration of traditional African culture, religion and world-view was combined with feelings of black inferiority which were expressed inter alia in a failure to ordain black ministers. In search of a sense of Christian belonging, Ethiopianism posed a direct challenge to the ecclesiastical status quo by promoting Africa for the Africans. It constituted a significant development in African Church history in the twentieth century. However, while it rejected the racism and domination of Protestant mission churches, it paradoxically maintained its ethos in many ways, e.g. in polity, theology

2 J. Mutero Chirenge, Ethiopianism and Afro-Americans in Southern Africa, 1883-1916 (London: Louisiana State University Press), 1987, 2.

3 Kevin Roy, Zion City, RSA (Cape Town: South African Baptist Historical Society), 2000, 88.

4 Along with other types of African-based churches, they are part of the African Initiated Church movement, also known as African Instituted Churches, African Indigenous Churches and African Independent Churches and, more recently, African International Churches (AICs). It is necessary to emphasise with Hastings $(1994,498-499)$ that secessions were by no means an African phenomenon, e.g. the disruption within the church in Scotland, 1843. 
and liturgy, often by absorbing elements which it considered positive in its faith expression. This 'indicates the versatility of African religion and its ability to absorb foreign religious practices without losing its identity. ${ }^{5}$

Ethiopians adhered to the principles of Venn and Anderson's three-self movement focused on churches becoming autonomous in respect of polity, mission and finance. Du Plessis ${ }^{6}$ commented somewhat unsympathetically: 'The history of Ethiopianism in general has made it abundantly clear that the natives are...to a large extent incapable of directing their own affairs and, in especial, their financial affairs.' Kalu ${ }^{7}$ disagrees: 'Ethiopians were ahead of their times and had started a process of reflection that perceived Christianity as a non-Western religion, asserted African contribution in the Jesus movement and sought to fashion an authentic African response to the gospel's good news.'

Many negative and unfounded comments basically undermined the integrity of the AICs by denying them authenticity. This led to claims that:

Whatever of religion and education exists among all the different tribes of South Africa is due to the expenditure of money by the great Missionary Societies of the home country and to the labours of the present and past generation of missionaries. These missionaries and societies naturally wish to consolidate their work, and if possible bring those churches they have fostered, to a position where they can be left as self-sustaining congregations in connection with the denominations which have created them. ${ }^{8}$

This tone suggests the expenditure incurred gave missions rights other than the high Christian motive of education and converting. It eschews the positive effects of missionary work that their products came to assert their independence in their own time and not that determined by the missionaries. Such critique forgets the missionary proclaimed intention of forming indigenous churches, though churches formed in their own image.

This form of 'homogeneous disaffection' concerned individual freedom of control from missionaries; and freedom for the community 'to forge an authoritative moral order, a community of ethical and social commitment, to which black Christians could bind themselves'. ${ }^{10}$ Ethiopianism represented black peoples' corporate liberation aspirations and their efforts to improve their religious, educational, political, economic and social status in society. The black people's approach to life

5 Marthinus L. Daneel, African earthkeepers: Wholistic interfaith mission (Maryknoll: Orbis), 2001, 119.

6 Du Plessis, J. A history of Christian missions in South Africa (London: Longmans Green), 1911, 457.

7 O.U. Kalu, African Christianity: An African story (Pretoria: Department of Church History, University of Pretoria), 2005, 259.

8 Editorial, Christian Express (CE), XXVII, 322, 1 April 1898, 45.

9 John L. Comaroff and Jean Comaroff, Of revelation and revolution: The dialectics of modernity on a South African frontier, vol. 2 (Chicago: University of Chicago Press), 1997, 101.

10 Comaroff and Comaroff, Of revelation and revolution, 101. 
was holistic, which explains why they saw no dichotomy in the challenge to their association of politics and religion. Hence, it is difficult to analyse Ethiopianism in separate and distinct dimensions.

Ethiopianism was not a homogeneous movement apart from its rising during the same period of the 'high' imperial and missionary era (1880-1920) ${ }^{11}$ :

Sometimes missionary occupation preceded, sometimes it followed annexation or political penetration; sometimes, as in Uganda, Nyasaland and Bechuanaland, it was intimately associated with the establishment of British overrule; sometimes as in eastern Nigeria, it was associated with the reconciliation of annexed peoples to a new way of life under the British crown. Occasionally as in the Upper Niger, it took place against the desire of the representatives of secular power. ${ }^{12}$

However, there are common features - response to colonialism, imperialism and the missionary movement and the response of nationalism throughout the African continent: 'Sometimes independency has articulated a radical political consciousness' in earlier periods. ${ }^{13}$

At the beginning of the eighteenth century, Kimpa Vita (Donna Beatrice) $)^{14}$ challenged the formalism of the Roman Catholic Church in the Portuguese kingdom of the Congo, attempted to inculturate Christianity in an African context and promoted protest against colonial rule and identification with African nationalism. She introduced the concept of a black Christ who identified with exploited Africans. Other protest and renewal movements arose throughout Southern Africa e.g. Mantsope Makheta (b. 1793) in Lesotho, Hendrik Witbooi, a type of political messiah among the Herero in South West Africa (1905), Enoch Mgijima in South Africa (1921), and the Chilembe rebellion in Nyasaland (1915). ${ }^{15}$ This prepared the way for the nineteenth century emergence and development of Ethiopianism in the broader context of Pan-Africanism.

\section{ORIGINS OF NINETEENTH CENTURY ETHIOPIANISM}

For Kalu, Ethiopianism has three broad strands - African American diasporic experience, western African and southern African expressions. ${ }^{16}$ These provided the energy which stimulated African nationalism: 'Ethiopia became a symbol of African

11 Andrew F. Walls, 'British missions', in T. Christensen and W.R. Hutchinson (ed.), Missionary ideologies in the imperialist era: 1880-1920 (Arrhus, Denmark: Forlaget Aros), 1982, 159, 161.

12 Walls, 'British missions', 161.

13 Elizabeth Isichei, A history of Christianity in Africa: From antiquity to the present (London: SPCK), 1995, 229.

14 Marthinus L. Daneel, Quest for belonging (Gweru: Mambo Press), 1987, 46-47.

15 Ross, K.R., Malawi and Scotland: Together in the talking place since 1859 (Mzuzu: Mzuni Press), 2012, 77-85.

16 Kalu, African Christianity, 265. 
redemption, political and religious ideology that continued to inspire through generations.' ${ }^{17}$ The 'Africa for the Africans' movement, exemplified in the African Methodist Episcopal Church, formed in 1815 in Philadelphia USA by Richard Allen ${ }^{18}$, contributed to the rise of Ethiopianism, expressed a corporate African cultural identity through its heritage, a distinctive African spirituality, Pan-Africanism and autonomy in terms of dealing with the hopes and fears of oppressed peoples who witnessed the partition and distribution of their land at the Berlin Congress of 18841885 without any consultation, leading Blyden to comment:

One of the subjects of this illustrious gathering was to decide the formalities to be observed for the valid annexation of the territory in future on the African continent...In keeping with the understanding arrived at in Berlin, Germany, France, England and Portugal have been appropriating African territory. ${ }^{19}$

These were black people about whom it could be said:

A strong sense of belonging and of security is important to them...people join the AIC through their concern for one another, establish a place where members can overcome the isolation, experience that natural African fellowship, enjoy recognition as a fellow human

being in need; and generally through consideration, care and love, be made to feel at home. ${ }^{20}$

Prior to this, missionary attitudes sometimes colluded with colonial policies and ideology and sometimes challenged it. After the Berlin Congress, attitudes changed for the worse, particularly racist attitudes. ${ }^{21}$

Another stimulus was the three-self principle..$^{22}$ In time, they also expressed a need to be self-reflecting/theologising which allowed for the inculturation of Christianity in an authentic meaningful way. Ethiopianism constituted an 'embryonic' or 'protonationalism ${ }^{23}$ fostering an enthusiastic and emotionally stimulating African ethos. However, it was reactive as well as proactive as it responded to negative forces encountered:

- Imported ecclesiastical disruptions, e.g. Scotland.

17 Kalu, African Christianity, 267.

18 Daneel, Quest for belonging, 50.

19 Edward W. Blyden, Christianity, Islam and the Negro race (Edinburgh: Edinburgh University Press), 1967, 347.

20 Maboea, S.I., 'Causes for the proliferation of the African Independent churches', in Gerhard C. Oosthuizen, M.C. Kitshoff and S.W.D. Dube (ed.) (Leiden: EJ Brill), 1994, 121-136, 127.

21 Kalu, African Christianity, 260.

22 Pretorius, H. and Jafta, L.D. 'A branch springs out', in Elphick, R. and Davenport, R. (eds.) 1997, Christianity in South Africa: A political, social and cultural history (Cape Town: David Philip), 1997, 212.

23 John S. Pobee and Gabriel Ositelu II, African initiatives in Christianity: The growth, gifts and diversities of indigenous African Churches - a challenge to the ecumenical movement (Geneva, WCC), 1998, 20, 22. 
- Discriminatory disciplinary standards.

- Unwillingness of white ministers to ordain blacks.

- Discriminatory stipend structures.

- Seeking after power and prestige especially with regard to control of church funds.

- Racism in European missionary controlled churches (a negative effect of

- 'proto-nationalism').

- Individualistic approach to Christian witness and faith.

- Inability and/or unwillingness of mission colonial churches to meet the aspirations of black membership.

Yet, numerous churches emerged with a positive outlook. The Church of the Lord (Aladura) in Nigeria aimed at renewal of its members through Christian teaching and prayer. The Church of Christ in Africa (Kenya) was established in 1959 by Matthew Ajuoga through a desire for reform and renewal, and Nehemiah Tile's Tembu National Church (South Africa) arose out of a positive desire to adapt the message of the Church to the heritage of the Tembu tribe. ${ }^{24}$

Ethiopianism found fertile ground among educated Africans who felt marginalised within mission churches, e.g. EW Blyden and PJ Mzimba. De Gruchy notes that: 'The Ethiopian pioneers were not ecclesiastical young turks, but seasoned evangelists who had internalised the missionary vision of individual mobility and racial progress more than their mentors had anticipated. ${ }^{25}$ Many churches of this genre were birthed prior to the independence movement towards the middle of the twentieth century and made a contribution to the drive for independence. Walshe argues that mission education contributed to the development of moral principles and individualism:

Given the questioning and often the partial rejection of tribal ethics and organisation, these principles were then extended to social and political activity, so providing the motivation, not for political assertion, but for moral appeals to justice even if these appeals were not backed up by effective political organisation. ${ }^{26}$

Lovedale was a prime example with its encouragement of black students to accept non-racial ideals and a multi-racial community in a Christian context which was both 'an integrating and disintegrating force', ${ }^{27}$ producing compliance and resistance. ${ }^{28}$

24 Bengt G. Sundkler, Bantu prophets in South Africa (Oxford: OUP), 1961, 38.

25 John W. de Gruchy, Christianity and the modernisation of South Africa: A documentary history, vol. II (Pretoria, UNISA Press, 18). Campbell, Songs of Zion, 125.

26 Peter Walshe, The rise of African nationalism in South Africa: The African National Congress, 1912-1952 (London: University of California Press), 1970, 7.

27 Walshe, The rise of African nationalism, 9-10.

28 Graham A. Duncan, Lovedale, coercive agency: Power and resistance in mission education (Pietermaritzburg: Cluster), 2003, 356. 


\section{PAN-AFRICANISM}

Pan-Africanism began in the USA among intellectuals of African descent, indigenous Americans and American black slaves to encourage the solidarity of Africans worldwide; those of the diaspora, including those who were victims of the slave trade $^{29}$ in the belief that unity is vital to economic, social and political progress and to unify and empower people of African descent; it asserted that the history and destiny of all African peoples and countries are intertwined. Pan-Africanism produced thinkers like Marcus Garvie and WEB Du Bois who propagated PanAfrican philosophy among the educated black elite in Africa; it was an independent African product, conceived in the Ethiopian movement. ${ }^{30}$ This ideal was developed and expressed by James Johnson in Sierra Leone towards the close of the nineteenth century.

The Ethiopian movement arose at a time when black people were developing a strong sense of self-worth (black consciousness) and self-reliance sourced in mission education (a Christian stimulus), where the spirit of pan-nationalism was fostered by young people from the African continent coming together to be educated. This produced a solidarity which provided a basis for Ethiopianism and a critical spirit. It instilled the confidence to challenge and act independently of racist mission structures. One significant effect of mission education was that it fostered a panregionalism through accepting students from southern Africa. At boarding schools, students who would never have left their home areas interacted with their peers from diverse ethnic backgrounds forming some enduring friendships which were strengthened when the young people graduated and took up employment in industrial centres. Black South Africans became aware of the futile struggle for representation within the Union in the early years of the twentieth century, 'in common with subject peoples throughout the world, developed concurrently with the more profound and continuing influence of Negro America' ${ }^{31}$ It was influenced by Du Bois and Garvie's Pan-Africanism. Many activists during the 1920s, members of the Industrial and Commercial Workers' Union, the Communist Party and the ANC came under Garvie's influence. He promoted the unity of black people and freedom which resulted from Afro-Americans repatriating their ancestral homelands. To achieve this he founded the Universal Negro Improvement Association in 1914. Pixley ka Seme echoed Du Bois's thinking. Reflecting on the glory of Africa's past history, he proclaimed 'a new and unique civilisation...thoroughly spiritual and humanistic

29 Kwame A. Appiah, 'Pan-Africanism, in Kwame A. Appiah, Henry L. Gates (ed.), Africana: The encyclopedia of the African and African American experience (New York, Basic Civitas), 1999, 1484-1486, 1484.

30 Gavin, R.J., 'Africa since independence', in A.E. Ayandele, A.E. Afigbo, R.J. Gavin and J.D. Omer-Cooper, The growth of African civilisation, vol. 2, The late nineteenth century to the present day (London: Longman), 1971, 375-395, 379.

31 Walshe, The rise of African nationalism, 90. 
- indeed a regeneration moral and eternal' ${ }^{32}$ This pan-regionalism, which was a source of modern African nationalism, enabled church secessionists to spread their brand of Christianity across national boundaries effectively.

TheEthiopian movement facilitated the promotion of nineteenth century, and later, Pan-African nationalism which transcended Western imported denominationalism and united black people. James Johnson was an early Pan-Africanist who supported African nationalism interrelated with religion and politics. He envisaged one African church for the entire continent, whose ethos, liturgy, polity and theology would display a distinctive African corporate personality, paralleled in the creation of one African state. He included Africans of the diaspora in his vision which was echoed by Blyden in Liberia, and John Chilembwe in Nyasaland. Blyden's awareness of the rapidly changing situation in Africa arising out of Western modernisation led him to develop a relevant ideology for the black race in which he blended Christian and Islamic ideas ${ }^{33}$ with traditional African philosophy. It was also integrated historically with its spiritual legacy. He reminded his fellow Africans that they already had achievements to be proud of in their wholesome culture and history ${ }^{34}$ and also promoted the concept of a distinctly African personality in contradistinction to the negative Christian personality implanted by missionaries. In the character of the African was to be found 'the softer aspects of human nature...cheerfulness, sympathy, willingness to serve' ${ }^{35}$ Blyden conceived the idea of a West African Church and encouraged fellow Africans to return to their roots in Africa and to their cultural and religious heritage under the slogan of unity: 'Africa for Africans'. Kalu affirms that:

Ethiopians laid the foundations for modern forms of African nationalism whether in the political or ecclesiastical realm and initiated the current debates on inculturation and vernacularisation in African theology. They voice a new form of Christianity in Africa. ${ }^{36}$

\section{RESPONSE TO COLONIALISM, IMPERIALISM AND THE MISSIONARY MOVEMENT}

This was the response of local 'agency' 'by which black people confronted colonial social structures and institutions' where colonialism refers to 'an administrative structure and a psychological instrument that humiliated and wounded the soul and made the victim dependent on the master figure'. ${ }^{37}$ All political actions and

32 Pixley ka Isaka Seme, 'The regeneration of Africa', a speech delivered at Columbia University, 5 April 1906, in WH Ferris, The African abroad, I, 437,439 (New Haven), 1913.

33 Hollis R. Lynch, Edward Wilmot Blyden: Pan-Negro patriot, 1832-1912 (Oxford, OUP), 1967, 67-77, cf. Isichei, A history of Christianity in Africa, 166.

34 Lynch, Edward Wilmot Blyden, 55

35 Lynch, Edward Wilmot Blyden, 62.

36 Kalu, African Christianity, 273.

37 Kalu, African Christianity, 264. 
ideological elements which aim to improve the status, the rights and position of Africans in the emerging society imposed by white intrusion and conquest, constitute African nationalism. The challenge was against 'empire' as 'the coming together of economic, cultural, political and military power that constitutes a system of domination led by powerful nations to protect and defend their own interests', ${ }^{38}$ and its handmaiden colonialism, its geographically defined expression with the aim of extending imperialism. It was cruel, dehumanising and the enemy of ubuntu, 'the antidote to empire'. ${ }^{39}$ It destroyed African memory: 'This is the result of nearly five centuries of internalising the empire's lies...Africans in the continent and in the diaspora need to know that they were birthed from a great people who have bequeathed humanity the earliest systems of civilisation'. ${ }^{40}$ Hardly an African nation avoided this situation. Nationalism sought to unite indigenous groups in the liberation struggle against racism and discrimination. Almost the entire continent had suffered from the intrusion of colonialism and imperialism and their alignments with the missionary movement, making it virtually impossible to distinguish motivations in particular instances. Blyden offers a telling example of independence derived from colonialism where Pan-Africanists':

... protégés take their place in Liberia, and come under the influences of the Fatherland [USA]. As they advance to maturity in the ancestral home [Africa], the propensity to imitation grows weaker and weaker, and their improving faculties gradually divert them from the models they left in the house of bondage, to ideal standards, more in accordance with their tastes and instincts. White is dethroned, and black takes its proper position. The habit of thinking, of observation, of reflection - without the disturbing action of any alien influence - adds, as it were, a new eye to the mind; slumbering faculties are aroused; and they learn many things, which, with less freedom to themselves, less responsibility, and less necessity for intellectual concentration, it would have been impossible for them to acquire. ${ }^{41}$

Empire was not restricted to or by political considerations:

The Ethiopian spirit was nursed in a political climate in which whites were aggressively expanding their spheres of influence throughout the African subcontinent. In these new developments Christian missionaries took an active part, some of them actually receiving encouragement from their societies to support colonial schemes. ${ }^{42}$

During the last quarter of the nineteenth century protest and resistance against political and economic domination increased in South Africa, particularly as a challenge to

38 Accra Confession: Covenanting for justice in the economy and the earth (Geneva: World Alliance of Reformed Churches), 2004, §11.

39 Prince Dibeela, 'In pursuit of a liberating humanism', in Prince Dibeela, Puleng Lenka-Bula and Vuyani Vellem (ed.), Prophet from the south: Essays in honour of Allan Aubrey Boesak (Stellenbosch: SUN Press), 2012, 231.

40 Dibeela, 'In pursuit of a liberating humanism', 240.

41 Blyden, Christianity, Islam and the Negro race, 365.

42 Chirenge, Ethiopianism, 40. 
Cecil J Rhodes's expansionist economic policies and activities. This was linked to the emergence of a black elite educated at mission establishments, "yet who were progressively restricted in their activities to their own areas ${ }^{43}$, and excluded from white society. Mission education was challenged by Mangena Mokone and others. Mokone's niece, Charlotte Maxeke wrote to her sister: 'Mokone asked for assistance in educating South African students at American colleges and for some advice on how to lead effectively the Ethiopian Church' ${ }^{44}$ while negotiations were under way with the AME church in the USA and Mokone was excited about this prospect. He wrote to Bishop Henry Turner in April 1896: 'Your favourable letter has been the cause of our revival and strengthening. We are always so strengthened when we receive letters from America, and feel as if we have been visited by an extraordinary being' ${ }^{45}$ This was a major avenue for young black South Africans' advancement and a sign of the growing awareness of the global dimensions of the black experience and black solidarity.

Within the Presbyterian tradition, Rev. Mpambani Mzimba was reared in the missionary culture and reacted against it in 1898 by seceding from the Scottish Mission to form the Presbyterian Church of Africa (PCA). Mzimba was minister at Lovedale which 'represented the confluence of the streams of imperialistic missionary and emergent African middle-class thought ${ }^{46} \mathrm{He}$ had concluded that the establishment of white majority rule had removed possibilities of advancement for black people. He was frustrated by his white colleagues' paternalism and discriminatory behaviour. Mzimba also had nationalistic aspirations believing that blacks had the potential for self-support and that independence made black people more persistent in their work ethic. ${ }^{47} \mathrm{He}$ felt that he had, as a senior black minister, the responsibility to take the initiative and thus became outspoken on African political rights, leading to a rupture between African nationalists and those who desired to enter European society. This became a significant factor of African nationalism post-1910.48

Aggrieved black people sought outlet for their aspirations in nationalism which led to the formation of the South African Native National Congress in 1912.49 Concurrent with this rising secular tide, a movement was emerging which spread rapidly in church life, expressing feelings of resentment which could not easily be expressed otherwise. This was the African Initiated Church (AIC) movement which

43 Graham A. Duncan, Scottish Presbyterian Church Mission Policy in South Africa, 1898-1923. MTh dissertation (Pretoria: UNISA), 1997, 67.

44 In Chirenje, Ethiopianism, 52.

45 In Chirenje, Ethiopianism, 55.

46 Greg C. Cuthbertson, "Cave of Adullam": Missionary reaction to Ethiopianism at Lovedale, 1898-1902', Missionalia, 19 (1, April, 1991), 57-64; 57

47 Brock, 'James Stewart', 286.

48 John W. de Gruchy, Christianity and the modernisation of South Africa: A documentary history, vol. II (Pretoria: UNISA Press), 2009, 16

49 Saul Dubow, The African National Congress (Thrupp, Gloucestershire: Sutton Publishing), 2000, 1. 
originated as a negative response to ecclesiastical oppression; it had positive features which account for its rapid growth and sustained existence, for:

...AICs have the potential of embodying a type of Christian spirituality and faith that does not merely contextualize some superficial elements of a Western interpretation of Christianity but rather represents a legitimate version of Christian faith, a non-Western religion, that has taken root in the distinctive heritage of that continent. ${ }^{50}$

'Independent Churches have... attempted to make a creative synthesis of traditional and Christian beliefs...they represent radical indigenisation and Africanisation of Christianity'. ${ }^{51}$ Negatively, AICs are a protest against 'the experience of religious manipulation, deculturalisation and racial subjugation' and positively as 'a part of the broad and long term process of national politico-economic emancipation. ${ }^{52}$

A similar response occurred elsewhere in Africa. Afigbo's evaluation is quite clear in terms of political effect:

Political awareness among the mass of the African population expressed itself in a religious form known as Ethiopianism...Though the Ethiopian movement was on the surface religious, it had a strong political element since it was an expression of African resentment at European dominance. The Ethiopian movement has little immediate political effect but it did serve to awaken and encourage political opposition to European control. The churches, too, offered a training ground for organising, administering, public speaking, committee work, etc. ${ }^{53}$

However, Lamola claims that:

In conceiving the reason for the founding of the Black Church as being primarily missiological...they were the formulators of the concept of Pan-Africanism. They preached that the church in colonial South Africa and the entire African population should be so developed, freed and equipped that it can go out and serve other people - "Africa for humanity". ${ }^{54}$

By the 1920s, numerous groups seceded from mainstream missionary churches. In South Africa the years 1910-1930 witnessed a 'new convergence of black political

50 Veli-Matti Kärkäinen, An introduction to Ecclesiology: Ecumenical, historical and global perspectives (Downer's Grove, Illinois: IVP Academic), 2002, 195.

51 Mothlabi, M., 1986. 'The historical origins of black theology', in Itumeleng J. Mosala and Buti Tlhagale, The unquestionable right to be free: Essays in black theology (Johannesburg: Skotaville), 1986, 80.

52 John M. Lamola, 'Towards a black church: A historical investigation of the African Independent Churches as a model', Journal of Black Theology in South Africa (JTSA), 1988, 2 (no.1, May): 5-14; J.W. Claasen, 'Independents made dependents'. Journal of Theology for Southern Africa, 1995, 95:15-34.

53 Afigbo, A.E., 'South Africa after the Union' in A.E. Ayandele, A.E. Afigbo, R.J. Gavin and J.D. Omer-Cooper, The growth of African civilisation, vol. 2, The late nineteenth century to the present day (London: Longman), 1971, 237-267, 261.

54 Lamola, 'Towards a black church', 12. 
opinion' stemming from black alienation arising out of the Treaty of Union (1910) which 'sealed their inferior political position. ${ }^{55}$ This fell within the classical period of Ethiopianism, i.e. 1882-1928. Clearly, Ethiopians saw a convergence of the political and the religious motives and methods.

\section{RESPONSE OF NATIONALISM IN THE POLITICAL SPHERE}

This section will focus specifically on the West African context. African nationalism is a political movement which aimed at national self-determination. It began in the 1870s and nationalist political organisations began to form in the 1890s with Edward Wilmot Blyden recognised as its founder. Nationalism is a philosophy, a form of culture, a social movement that focuses on the nation as a cohesive unit. It emphasises the community of a specific nation and promotes the philosophy that the people constitute the nation. African nationalism is a political movement for the unification of Africa (Pan-Africanism), national self-determination and the transformation of African identity. Rather than seeing themselves as Zulu, Sotho, etc., nationalist leaders wanted Africans to view themselves as Africans. After World War I, nationalists throughout Africa began to develop self-determination.

Ethiopianism in Nigeria expanded on the base of large numbers of educated black people. It emerged as a form of proto-nationalism expressed through the press. ${ }^{56}$ It grew exponentially during the period 1888-1917. Black nationalist opinion grew, linked to disenchantment with Western dominated Christianity.

The African Methodist Episcopal Zion Church (AMEZ) which was established in Ghana in 1898, began in the USA in 1796. Bishop John Bryan Small, who had served in Ghana (1863-1896) in the West Indian regiment, brought the AMEZ to Ghana. A branch of the church was formed at Cape Coast by Thomas Freeman. ${ }^{57}$ Another branch was established at Keta, supported by disillusioned Methodists and many with nationalist aspirations. A Methodist secession led to the birth of the United African Methodist Church in 1917. The AMEZ was inspired by nationalist feelings. Part of the Africanisation policy involved sending young able students to the USA for education. Foremost amongst these was JEK Aggrey who became a leading African educationist. The AMEZ was led by a group of outstanding black men who espoused strong nationalist and Christian commitment, such as Rev. Dr Ata Osam Pinako who believed that Christianity and nationalism together could achieve the liberation of black people. There was a stronger relation between religion and politics than has often been recognised. Appiah-Kubi notes that in addition to 'political, economic,

55 Lamola, 'Towards a black church', 11.

56 Isichei, A history of Christianity in Africa, 179.

57 Isichei, A history of Christianity in Africa, 168-169. 
and social deprivation and racial discrimination, ${ }^{58}$ the quest for an Akan spirituality with an authentic identity was crucial in the formation of Ethiopianism.

AICs were a "catalyst for this political surge' ${ }^{59}$ of black nationalism which spread through mission stations towards the end of the nineteenth century. Mission and evangelism in the mission churches had 'separated the gospel from the historical and material context of the people addressed' ${ }^{60}$ AICs accommodated Christian beliefs to the realities of black peoples' lives; they related Christianity with black history and identity and were, therefore, 'Ethiopian'; they wished the organisation of churches to be controlled by blacks.

A politically significant movement was born in the context of a self-awareness of oppression as a source of challenge to Western understandings of the gospel. This was fostered by the development of the African press which stimulated awareness amongst black people. This was an aspect of mission education effect of encouraging resistance. This was also a factor which stimulated the desire among blacks to be educated in the USA where the educated elite came into contact with black autonomous churches like the AMEC under the influence of Rev. Henry Turner, who proclaimed that 'God is a Negro'. ${ }^{61}$

This is one of the reasons we favour African emigration, or Negro nationalization, wherever we can find a domain, for as long as we remain among whites, the Negro will believe that the devil is black and that he (the Negro) favors the devil, and that God is white and he (the Negro) bears no resemblance to Him, and the effect of such a sentiment is contemptuous and degrading, and one-half of the Negro race will be trying to get white and the other half will spend their days trying to be white men's scullions in order to please the whites; and the time they should be giving to the study of such things that will dignify and make our race great will be devoted to studying about how unfortunate they are in not being white. ${ }^{62}$

Turner also expressed strong Pan-Africanist views by demarcating the parameters of civilisation in the USA as he knew it and recommended that young Afro-Americans emigrate to a less race ridden South Africa: 'Those things...constitute the very nest

58 Kofi Appiah-Kubi, 'Indigenous African Christian churches: Signs of authenticity', in Kofi AppiahKubi and Sergio Torres (ed.), African theology en route (Maryknoll: Orbis), 1979, 117-125, 117.

59 Greg C. Cuthbertson, 'Missionary imperialism and colonial warfare: London Missionary Society attitudes to the South African War, 1899-1902.' South African Historical Journal, 1987, 19:93114,84 .

60 James R. Cochrane, Servants of power: The role of the English speaking churches in South Africa 1903-1930 (Johannesburg, Ravan), 1987, 156.

61 Paul Harvey, Through the storm, through the nightl: A history of African American Christianity (Plymouth: Rowan \& Littlefield), 2011, 165,

62 Henry McNeal Turner, 'Voice of missions', February 1898; reprinted in Respect black: The writings and speeches of Henry McNeal Turner, ed. Edwin Redkey (New York: Arno Press), 1971, 176-177. 
egg of civilisation and only their successful and permanent development out of a people's own resources can ever bring national vigor and strength. ${ }^{93}$

While the Ethiopian movement was disruptive in a negative sense, it was also incorporative in the sense of seeking 'to promote Christianity and unity in the whole continent of Africa ${ }^{64}$ In the southern African context, the "encounter with Ethiopianism [w] as a formative stage in the rapid politicisation of an African elite'. ${ }^{65}$ It was the sole religio-political movement. The Ethiopians saw a convergence of the political and the religious motives and methods. Afigbo's evaluation is clear:

Political awareness among the mass of the African population expressed itself in a religious form known as Ethiopianism...Though the Ethiopian movement was on the surface religious, it had a strong political element since it was an expression of African resentment at European dominance.

The Ethiopian movement had little immediate political effect but it did serve to awaken and encourage political opposition to European control. The churches, too, offered a training ground for organising, administering, public speaking, committee work, etc. ${ }^{66}$

\section{However:}

...they were the formulators of the concept of Pan-Africanism. They preached that the church in colonial South Africa and the entire African population should be so developed, freed and equipped that it can go out and serve other people - "Africa for humanity". ${ }^{67}$

The Afro-American James 'Holy' Johnson's Pan-Africanism envisaged African nationalism related to both church and state:

Africa is to rise once more; Ethiopia is to stretch her hands out unto God, her tears are to be wiped off her eyes... her Christian colleges are to be re-established, her native literature is to revive, and science again is to dwell in her, the word of the Lord above all is to cover her as the waters do the mighty deep: where this will be the case then she will take her place with the most Christian, civilised and intelligent nations of the earth. ${ }^{68}$

His Pan-Africanism was pan-denominational:

6320 April 1898, in Chirenje, Ethiopianism, 61.

64 Rev. J.C. Xaba cited in Francis Wilson F. and D. Perrot (ed.) 1972. Outlook on a century: South Africa 1870-1970 (Lovedale: Lovedale Press), 1972, 155.

65 Greg C. Cuthbertson, "Cave of Adullam": Missionary Reaction to Ethiopianism at Lovedale, 1898-1902. Missionalia 19 (no.1, April, 1991): 57-64, 64.

66 A.E. Afigbo, 'South Africa after the Union', in A.E. Ayandele, A.E. Afigbo, R.J. Gavin and J.D. Omer-Cooper, The growth of African Civilisation, vol. 2, The late nineteenth century to the present day (London: Longman), 1971, 237-267, 261.

67 Lamola, 'Towards a black church', 12.

68 James Johnson, 'Christian revival in Africa' in Klaus, Korschorke, Frieder Ludwig and Mariano Delgado (ed.), A history of Christianity in Asia, Africa, and Latin America, 1450-1990: A documentary sourcebook (Grand Rapids, Eerdmans), 2007, 217. 
The desire to have an independent church closely follows the knowledge that we are a distinct race, existing under peculiar circumstances and possessing peculiar characteristics, the desire to preserve this distinction uninjured, the conviction that it would materially contribute to a purely native character and power to our religious profession, and that the arrangement of foreign churches made to suit our own local circumstances can hardly be expected to suit our own in all their details. ${ }^{69}$

\section{PAN-AFRICANISM LINKED TO ETHIOPIANISM IN THE RELIGIOUS SPHERE}

This section focuses mainly on the East African context. Early in the nineteenth century a twin pronged American connection developed between Africa and the USA, which had its roots in the forced removal of slaves from West Africa to the USA. From 1787 emigration societies sent Afro-Americans to settle in Sierra Leone and in 1821 the AMEC $^{70}$ sent missionaries to Liberia. The AMEC was also a mission church which sought to promote the Christian development of black people without paternalistic and racist overtones. Consequently, 'African American black churches [played a role in] catalysing and sustaining African radicalism'. ${ }^{71}$ Bishop Turner became a key player in the emigration movement and the Ethiopian church movement. Turner was concerned to relocate African Americans who were confronted by American racism. Blyden surmised in a combination of myth and history that:

...Africa may yet prove to be the spiritual conservatory of the world. Just as in past times, Egypt proved the stronghold of Christianity after Jerusalem fell, and just as the noblest and greatest of the Fathers of the Christian Church came out of Egypt, so it may be, when the civilised nations, in consequence of their wonderful material development have had their spiritual perceptions darkened and their spiritual susceptibilities blunted through the agency of a capturing and absorbing materialism, it may be, that they may have to resort to Africa to recover some of the simple elements of faith; for the promise of that land is that she shall stretch forth her hands unto God. ${ }^{72}$

69 Cited in Ayandele, E.A., 'Holy' Johnson: Pioneer of African nationalism, 1836-1917 (Southgate: Frank Cass), 1970, 42.

70 A church whose origin lay in the poor racist context of diaspora Africans in the USA in the proand post-slave emancipation era. It focused on education, literacy empowerment and the self upliftment of black people. It had itself withdrawn from the white Methodist Church in the USA in 1787 as a result of racial discrimination. Its mission work was based on the concept of there being a distinct link between Africans of the diaspora and those in the African continent See James T. Campbell, Songs of Zion: The African Methodist Episcopal Church in the United States and South Africa (Oxford, Oxford University Press), 1995.

71 Kalu, African Christianity, 273.

72 Edward W. Blyden, Christianity, Islam and the Negro race (London: WB Whittingham), 1888, 143. 
This unity challenged racism and ethnocentrism and celebrated people's African tradition. It was also corrective to Christian teaching which reduced the black peoples' inferior self-image. ${ }^{73} \mathrm{He}$ valued religion to the extent that it advocated a positive self-image. Blyden's vision of African unity, encapsulated in his concepts of African personality (Negritude, Pan-Negro nationalism and Pan-Africanism), were influential in the growth and development of Ethiopianism.

In East Africa much of the African response to mission Christianity was directed against the Anglican Church. Reuben Musaka challenged the paternalism of Anglican missionaries. In the 1920s, he had been involved with Garvey's Pan-African movement and came under the influence of Bishop DW Alexander of Beaconsfield in South Africa. Subsequently he broke away from the Anglicans and invited Alexander to East Africa in 1931-2. He and his colleague Basaajakitalo were ordained as priests in the African Orthodox Church, but later Musaka moved to the Greek Orthodox Church. He was a secessionary in the true sense of Ethiopianism, being one who split from an established church and subsequently left that church to join another. In 1946, he visited the Greek Orthodox Patriarch in Alexandria, This visit led to the recognition of the Orthodox Church in Baganda and to the Baganda being enabled to study in Alexandria and Athens. One of these students, TH Nankyama, later became a bishop. By this time the Orthodox Church in Uganda numbered 10000 members. The Orthodox Church in Kenya grew quickly and resulted in a theological seminary being opened in Nairobi. The spirit of revival became common in East Africa in what became known as the Balokole and was susceptible to schism as in other places. In 1948, Ishmael formed a small denomination based on free love. Another breach with the Anglican Church in Kenya led Matthew Ajuoga and a group of clergy to the Church of Christ in Africa in 1957. Women were often instrumental in missionary initiatives. ${ }^{74}$

In Zimbabwe, Ethiopian churches consisted of non-prophetic movements, some of which were akin to Protestant mission churches, while others are linked ideologically and religiously to the Ethiopian state. They were influenced by similar South African and Malawian movements. They include Rev. Sengwayo's African Congregational Church (Chibaritwe), Bishop Gavure's First Ethiopian Church (FEC, Topia) and Rev. Sibambo's African Reformed Church. Mupambi Chidembo who was a muNdau from the Bikita district in the southeast formed the First Ethiopian Church (FEC) among the Shona. He was a migrant labourer in the Transvaal from 1890-1910 where he was exposed to Ethiopianism. On his return, now a bishop, he established congregations among the Duma and Shona peoples. His gains were modest until the 1940s when his nephew, Nheya Gavure, began to inspire support for the FEC. He assumed leadership of the church in 1952 and through his integrity and spiritual fervour it expanded mainly in the Bikita and Zaka districts. Gavure became

73 Lynch, Edward Wilmot Blyden, 60.

74 Isichei, A history of Christianity in Africa, 243. 
a leader of ecumenical stature in the Shona Independent Churches from 1972 and was president of Fambidzano (Council of Independent Shona Churches). ${ }^{75}$

The African Congregational Church (ACC), formed in 1942 by Mheke Sengwayo in predominantly Ndau territory, also has its roots in contacts with the Ethiopian movement in South Africa. Sengwayo, a muKozwi from the Chipinga district, left the American Board Mission (ABM) as the result of tension with the white missionaries at Mt Selinda. He had an affinity with South African Congregationalists who had parted from the ABM and following a period in South Africa returned to develop the ACC in his home area. He was supported by other former ABM members. ${ }^{76}$ Other Ethiopian churches formed include Francis Nyabadza's Church of St Francis (1942), Madida Moyo's Apostolic Faith Mission Church in 1945, and Esau Nempare's African Methodist Church in 1947. The AMEC had little success in Zimbabwe. ${ }^{77}$

From 1950, influential Dutch Reformed Mission Church members, including Moses Ruwana, Zvobgo and Chirashanye, led their followers from the Masvingo, Gutu and Bikita districts into the ACC. Under Ruwana's leadership traditional practices were incorporated into church life as a reaction against the historical churches and a demonstration of their African credentials. By the 1960s there were 8000 members with six ministers. Unfortunately, Africanisation led to schism and the formation of the African Reformed Church (Shonganiso Mission) in 1953. This church resembled the Dutch Reformed Mission Church with its insistence on monogamy, sobriety and rejection of divination and ancestor veneration. Rev. Zvobgo stated the spirit of the new church:

The organization of our African Reformed Church is not directed at breaking down the work of the DR missionaries, but to further our own activities in the spirit of remembrance that our church originated from, the "vaDutchi" our spiritual fathers. ${ }^{78}$

South African Ethiopianism was a significant factor in the origin and growth among the Shona people. These churches achieved autonomy at an early stage of their life. However, while South African Ethiopianism began to wane in the 1930s, Zambian Ethiopianism began to expand significantly.

In Zambia, Alice Lenshina Mulenga's prophetic Lumpa Church may be described as a prophetic and Ethiopian-type church. She emphasised the eschatological message and promised redemption for those who gave up objects related to magical rites prior to their baptism. She succeeded where the missionaries failed in this respect by strict application of the Church of Scotland's rules and discipline which became a unifying focus in the movement. The Bible and the sacrament of Holy Communion were jettisoned while traditional practices were developed, e.g. dance and polygamy.

75 Daneel, Quest for belonging, 51-52.

76 Daneel, Quest for belonging, 52.

77 Isichei, A history of Christianity in Africa, 248.

78 Daneel, Quest for belonging, 53. 
Racism was not tolerated. During the emergency in 1957, the movement was described as an Ethiopian-type political group. Conflict arose with the government due to Lenshina's refusal to support unconditionally the UNIP political party. ${ }^{79}$

\section{ECUMENICAL SIGNIFICANCE AND CONCLUSION}

Ethiopian churches were anti-denominational in their rejection of the ethos of imported denominations from Europe and the USA. Yet, they often retained denominational trappings. They were more open to common causes as with their involvement in and promotion of Pan-Africanism. Thus, 'Ethiopia became a symbol of African redemption, political and religious ideology that continued to inspire through generations' ${ }^{80}$

AICs, including Ethiopian-type churches, outgrew the historic churches both in numbers and in development of appropriate liturgy, polity, finance and mission. Historically, they made sacrifices; by seceding from mission agencies they denied themselves what they most yearned for - education. Now they are beginning to make a theological impact too, and though there is a persistent negative attitude towards the perceived lack of theology in AICs, theology is significant in the effect it has on people's lives. It may be credited as more enacted ${ }^{81}$ than thought out theology. It can be said that "Ethiopians" were ahead of their time and... started a process of reflection that perceived Christianity as a non-Western religion. ${ }^{82}$

There is considerable spontaneity in their forms of a missionary outreach which springs from the assumption that mission is integral to the life of the church. They are ecumenical, constituting a challenge to traditional ways of thinking by affirming that there are other ways of expressing the Christian faith apart from Western imposed ways:

Reality is expressed in culturally contradictory forms. Once that is accepted, we have to make serious concessions concerning other theological categories. ${ }^{83}$

The tendency of indigenous churches to schism is common among most of the historic churches; compare, for example, the Methodists and Presbyterians in South Africa. Yet, as a positive outcome, this has led to growth and renewal in some indigenous churches. They are 'missionary churches par excellence'. ${ }^{84}$ Membership

79 Daneel, Quest for belonging, 129.

80 Kalu, African Christianity, 267.

81 Daneel, African earthkeepers, 280.

82 Ogbu U. Kalu, Ethiopianism in African Christianity', in Ogbu U. Kalu (ed.) African Christianity: An African Story (Pretoria, Department of Church History, University of Pretoria), 2005, 258-277, 259.

83 Hollenweger to Tatchell, 9 December 1981, WCC archives.

84 Marthinus L. Daneel and Dana L. Robert 2000, 'Series preface' in Kritzinger, J.N.J. (ed.) Missionalia, 28 (2/3, November, i. 
implies commitment and participation in a corporate identity by allowing them to re-connect with their pre-European experience in a context of rising consciousness and nationalism arising out of growing rejection. Kalu summarises the contribution of Ethiopianism:

Ethiopians laid the foundations for modern forms of African nationalism whether in the political or ecclesiastical realm and initiated the current debates on inculturation and vernacularisation in African theology. They voiced a new form of Christianity in Africa. ${ }^{85}$

In the final analysis, this matter concerns freedom; freedom to choose what kind of ecclesiastical structure, witness and expressions in form and content best reflect the inner nature of the people concerned and best foster the spiritual development of that community as part of their total integrated lifestyle as a constituent of growing the Kingdom of God.

\section{LIST OF REFERENCES}

Afigbo, A.E. 'South Africa after the Union.' In A.E. Ayandele, A.E. Afigbo, R.J. Gavin and J.D. Omer-Cooper, The growth of African civilisation, vol. 2, The late nineteenth century to the present day. London: Longman, 1971, 237-267.

Appiah, K.A. 'Pan-Africanism.' In Kwame, A., Appiah, Henry, L. Gates (ed.), Africana: The encyclopedia of the African and African American experience. New York: Basic Civitas, 1999, 1484-1486.

Appiah-Kubi, K. 'Indigenous African Christian churches: Signs of authenticity.' In Kofi AppiahKubi and Sergio Torres (ed.), African theology en route. Maryknoll: Orbis, 1979, 117-125.

Ayandele, A.E. 'Holy' Johnson, pioneer of African nationalism, 1836-1917. Southgate: Frank Cass, 1970.

Blyden, E.W. Christianity, Islam and the Negro race. London, WB Whittingham, 1888. Edinburgh, University Press, 1967.

Brock, S. James, Stewart and Lovedale: A reappraisal of missionary attitudes and African response in the Eastern Cape, South Africa, 1870-1905. PhD thesis, Edinburgh: University of Edinburgh, 1974, Abstract.

Campbell, J.T. Songs of Zion: The African Methodist Episcopal Church in the United States and South Africa. Oxford: Oxford University Press, 1995.

Chirenge, J.M. Ethiopianism and Afro-Americans in Southern Africa, 1883-1916. London, Louisiana State University Press, 1987.

Christian Express (CE), Editorial, XXVII, 322, 1 April 1898, 45.

Cochrane, J.R. Servants of power: The role of the English speaking churches in South Africa 1903-1930. Johannesburg: Ravan, 1987.

Comaroff, J.L. and Comaroff, J. Of revelation and revolution: The dialectics of modernity on a South African frontier, vol. 2. Chicago: University of Chicago Press, 1997.

85 Kalu, African Christianity, 273. 
Cuthbertson, G.C. "“Cave of Adullam": Missionary reaction to Ethiopianism at Lovedale, 18981902', Missionalia, 19(1, April, 1991), 57-64.

Cuthbertson, G.C. 'Missionary imperialism and colonial warfare: London Missionary Society attitudes to the South African War, 1899-1902.' South African Historical Journal, 1987, 19: 93-114.

Daneel, M.L. Quest for belonging. Gweru: Mambo Press, 1987.

Daneel, M.L. and Dana, R.L. 'Series preface.' In Kritzinger, J.N.J. (ed.) Missionalia, 28 (2/3, November, 2000), i.

Daneel, M.L. African earthkeepers: Wholistic interfaith mission. Maryknoll: Orbis, 2001.

De Gruchy, J.W. Christianity and the modernisation of South Africa: A documentary history, vol. II. Pretoria: UNISA Press, 2009.

Dibeela, P. 'In pursuit of a liberating humanism.' In Dibeela, P., Lenka-Bula, P. and Vellem, V. (ed.), Prophet from the south: Essays in honour of Allan Aubrey Boesak. Stellenbosch: SUN Press, 2012.

Du Plessis, J. A history of Christian missions in South Africa. London: Longmans Green, 1911.

Dube, J.L. 'The Ethiopian call to Africa' Extracts from J.L. Dube, 'A talk to my native land.' In Karis, T. and Carter, G. (ed.), From protest to challenge: A documentary history of African politics in South Africa, 1882-1964, vol. I, Protest and hope, 1882-1934. Stanford California: Hoover Institute Press, 68-69.

Dubow, S. The African National Congress. Thrupp, Gloucestershire: Sutton Publishing, 2000.

Duncan, G.A. 'Scottish Presbyterian Church mission policy in South Africa, 1898-1923. Pretoria: UNISA, MTh dissertation, 1997.

Duncan, G.A. Lovedale, coercive agency: Power and resistance in mission education. Pietermaritzburg: Cluster, 2003.

Du Plessis, J. A history of Christian missions.

Gavin, R.J. 'Africa since independence.' In Ayandele, A.E., Afigbo, A.E.R., Gavin, R.J. and Omer-Cooper, J.D. The growth of African civilisation, vol. 2, The late nineteenth century to the present day. London: Longman, 1971, 375-395.

Hastings, A. The church in Africa: 1450-1950. Oxford: Clarendon, 1994.

Harvey, P. Through the storm, through the night: A history of African American Christianity. Plymouth: Rowan \& Littlefield, 2011, 165.

Isichei, E. A history of Christianity in Africa: From antiquity to the present. London: SPCK, 1995.

Johnson, J. 'Christian revival in Africa.' In Korschorke, K., Ludwig, F. and Delgado, M. (ed.), A history of Christianity in Asia, Africa, and Latin America, 1450-1990: A documentary sourcebook. Grand Rapids: Eerdmans, 2007, 217.

Kalu, O.U. (ed.). African Christianity: An African story. Pretoria: Department of Church History, University of Pretoria, 2005, 259.

Kalu, O.U. Ethiopianism in African Christianity.' In Ogbu U Kalu (ed.), African Christianity: An African story. Pretoria, Department of Church History, University of Pretoria, 2005, 258277, 259.

Kärkäinen, V.M. An introduction to Ecclesiology: Ecumenical, historical and global perspectives. Downer's Grove, Illinois: IVP Academic, 2002. 
Lamola, J.M. 'Towards a black church: A historical investigation of the African independent churches as a model.' Journal of Black Theology in South Africa (JTSA), 1988, 2(1, May): 5-14.

Lynch, H.L. Edward Wilmot Blyden: Pan-Negro patriot, 1832-1912. Oxford: OUP, 1967.

Maboea. 'Causes for the proliferation of the African Independent churches.' In Oosthuizen, G.C., Kitshoff, M.C. and Dube, S.W.D. (ed.). Leiden: EJ Brill, 1994, 121-136.

Mothlabi, M. 1986. 'The historical origins of black theology.' In Mosala, I.J. and Tlhagale, B, The unquestionable right to be free: Essays in black theology. Johannesburg: Skotaville, 1986.

Pobee, J.S. and Ositelu, G. African initiatives in Christianity: The growth, gifts and diversities of indigenous African Churches - a challenge to the ecumenical movement. Geneva: WCC, 1998.

Pretorius, H. and Jafta, L.D. ‘A branch springs out.' In Elphick, R. and Davenport, R. (eds) 1997. Christianity in South Africa: A political, social and cultural history. Cape Town: David Philip, 1997.

Ross, K.R. Malawi and Scotland: Together in the talking place since 1859. Mzuzu: Mzuni Press, 2012.

Roy, K. Zion City, RSA. Cape Town: South African Baptist Historical Society.

Seme, P.I. 'The regeneration of Africa', a speech delivered at Columbia University, 5 April 1906, in W.H. Ferris, The African abroad, 1, 437,439. New Haven, 1913.

Sundkler, B.G. Bantu prophets in South Africa. Oxford: OUP, 1961.

Turner, H.M. 'Voice of missions', February 1898; reprinted in Respect black: The writings and speeches of Henry McNeal Turner, (ed.) Edwin Redkey. New York: Arno Press, 1971, 176177.

Walls, A.F. 'British missions.' In T. Christensen and W.R. Hutchinson (ed.), Missionary ideologies in the imperialist era: 1880-1920.

Walshe, P. The rise of African nationalism in South Africa: The African National Congress, $1912-$ 1952. London: University of California Press, 1970.

WCC Archives. Hollenweger to Tatchell, 9 December 1981, Geneva, WCC.

Wilson, F. and Perrot, D. (ed.) 1972. Outlook on a century: South Africa 1870-1970. Lovedale: Lovedale Press, 1972.

World Alliance of Reformed Churches. Accra Confession: Covenanting for justice in the economy and the earth, Geneva: World Alliance of Reformed Churches, 2004.

\section{Additional sources consulted}

Duncan, G.A. 'African churches willing to pay their own bills': The role of money in the formation of Ethiopian-type churches with particular reference to the Mzimba secession, African Historical Review, 45:2, 52-79, 2013, DOI: 10.1080/17532523.2013.857092.

Hinchliffe, P. The church in South Africa. London: SPCK, 1968.

Mansel Heale, J.P. A chapter of Genesis, 1896, cited in Lynch, Edward Wilmot Blyden. 